\title{
Characteristics of physical activity programs in the Brazilian primary health care system
}

\section{Características de programas de atividade física na atenção básica de saúde do Brasil}

\section{Características de los programas de actividad física en la atención primaria de salud en Brasil}

Grace Angélica de Oliveira Gomes 1,2 Eduardo Kokubun 2 Grégore Iven Mieke 3

Luiz Roberto Ramos 4

Michael Pratt 5

Diana C. Parra 6

Eduardo Simões 6

Alex A. Florindo 7

Mario Bracco ${ }^{8}$

Danielle Cruz 9

Deborah Malta 9

Felipe Lobelo 5,10

Pedro C. Hallal 3

\footnotetext{
${ }^{1}$ Departamento de

Gerontologia, Universidade

Federal de São Carlos, São

Carlos, Brasil.

2 Núcleo de Atividade

Física, Esporte e Saúde,

Universidade Estadual

Paulista, Rio Claro, Brasil.

3 Grupo de Estudos em

Epidemiologia da Atividade

Física, Universidade Federal

de Pelotas, Pelotas, Brasil.

${ }^{4}$ Universidade Federal de São

Paulo, São Paulo, Brasil.

5 National Center for Chronic

Disease Prevention and

Health Promotion, Centers

for Disease Control and

Prevention, Atlanta, U.S.A.

6 George Warren Brown

School of Social Work,

Washington University in St.

Louis, St. Louis, U.S.A.

7 Escola de Artes, Ciências e

Humanidades, Universidade

de São Paulo, São Paulo,

Brasil.

${ }^{8}$ Hospital Israelita Albert

Einstein, São Paulo, Brasil.

${ }^{9}$ Ministério da Saúde,

Brasília, Brasil.

${ }^{10}$ Rollins School of Public

Health, Emory University,

Atlanta, U.S.A.

Correspondence

G. A. O. Gomes

Departamento de

Gerontologia, Universidade

Federal de São Carlos.

Rod. Washington Luis Km

235, São Carlos, SP

13565-905, Brasil.

graceaogomes@yahoo.com.br
}

\section{Resumo}

O objetivo foi descrever as características dos programas de atividade física na atenção básica de saúde de acordo com a presença de Núcleo de Apoio à Saúde da Família (NASF) no município e por regiões do Brasil. Foi realizado um estudo transversal por inquérito telefônico com 1.251 coordenadores de unidades de saúde. Foi aplicado um questionário sobre presença de intervenções com atividade física e suas características de funcionamento. Quatro em cada dez unidades de saúde relataram ter uma intervenção com atividade física, especialmente grupos de caminhada. A maior parte da atividade é realizada na manhã uma vez ou duas vezes por semana, com sessões de 30 minutos ou mais. Profissionais de educação física são os principais responsáveis por supervisionar as atividades. Os programas ocorrem na unidade de saúde ou outros espaços comunitários. Estas características, de modo geral, foram semelhantes entre unidades com ou sem NASF no município e apresentaram variação entre as regiões. Os resultados desse estudo irão permitir melhor direcionamento das próximas ações de promoção de atividade física na atenção básica de saúde.

Motor Activity; Developing Countries; Primary Health Care; Family Health
Atividade Motora; Países em Desenvolvimento; Atenção Primária à Saúde; Saúde da Família 


\section{Introduction}

Physical inactivity is a global pandemic 1 , responsible for $9 \%$ of premature mortality worldwide in 2008 2. In order to reduce the high proportion of inactive individuals around the world 3 , the implementation of incentive programs as well as mobilization and support for physical activity programs have been considered priority strategies to promote health in many countries $4,5,6$. Specifically in low and middle-income countries, the emphasis of public health policies has been on groups who have less access to physical activity opportunities 7,8. However, there is still ample room for improvement regarding the central role that public policy can play in the promotion and facilitation of healthy lifestyles, particularly in low and middle-income countries 9 .

Brazil has a Unified National Health System (SUS) that uses primary health care settings as the first step for prevention and treatment. Primary care clinics are one of the potential entry points to deliver physical activity counseling and referral to programs linked to the corresponding health care model in Brazil. One of the pillars of this model is the Family Health Strategy (FHS), which covers $47.7 \%$ of registered households in Brazil, with a higher proportion in the Northeast of the country 10. Family Health Teams (FHT), composed of a general physician, nurse and community health agents, have responsibilities in a delimited territory encompassing around 800 to 1,000 families to provide health promotion, prevention and rehabilitation actions, and resolve some of the most frequent health problems that affect the community. To support and improve the actions of the FHTs, the Multidisciplinary Primary Care Teams [Núcleo de Apoio à Saúde da Família - NASF] was created to share health practices and specific knowledge in diverse areas with the FHTs. The NASF is composed of different health professionals including nutritionists, physical educators, physiotherapists, psychologists, speech therapists, occupational therapists, psychiatrists, and social workers, among others, who work together with primary care teams to support and develop health practices in the population 11 .

The promotion of physical activity has been encouraged in accordance with primary health care policies 12. For example, in April 2011, the Brazilian Ministry of Health launched the Academia da Saúde (Health Gym) program which designated specific spaces for physical activity in Brazilian municipalities within the primary care framework 3,8,13,14. In addition, physical activity interventions have been carried out as a strategy to promote health in this setting 15,16.
Existing programs have behavioral, environmental and educational components. They occur in accordance with the socioeconomic and cultural differences found in each municipality. Several types of interventions have been utilized including informational lectures, supervised physical activities, and counseling by health professionals 17,18 . International studies have shown a positive relationship between participation in programs to increase physical activity and levels of physical activity, as well as improvements in health conditions of the population 17,19. Much of this evidence on effective community physical activity programs comes from Brazil 20,21,22,23,24.

Recent meta-analyses of randomized clinical trials of physical activity counseling and referral programs indicate that this approach can be effective in helping inactive individuals become more active and to meet current physical activity recommendations 13,25. Regular physical activity counseling by primary care providers is a national public health objective in the United States of America ${ }^{26}$. In addition, physical activity counseling has been shown to be cost-effective, and is part of primary care systems in the United Kingdom 27 , Sweden and Switzerland ${ }^{28}$. In general, participation in a physical activity program in primary health care in Brazil starts with counseling from a health professional (physician, nurse, community worker), followed by an invitation to participate in a program sponsored by the primary care unit. Program awareness in many cities is also enhanced through special events and community educational activities performed by the health units 16 .

However, to our knowledge there are few reports describing physical activity counseling and referral schemes in the primary care settings in middle income countries such as Brazil 16,24,29. An in-depth overview of the FHT physical activity program in Brazil may help guide future actions to maintain and improve existing programs, evaluate their effectiveness and cost-effectiveness, and encourage research that leads to the replication or implementation of similar interventions in other low-to-middle income countries. Thus, the objective of this study was to describe the characteristics of physical activity interventions implemented in primary health care units in Brazil.

\section{Methods}

This study was developed by GUIA (Guide for Useful Interventions for Physical Activity in Latin America), a project designed to assess and pro- 
mote evidence-based strategies to increase physical activity in Latin America 30,31. A cross-sectional study was conducted with a random-digit-dial telephone survey directed at physicians, nurses, community health workers and managers working in primary health care units in Brazil. These units were classified as Family Health, Traditional, or Mixed (Traditional units with FHS) according to the presence or absence of the FHS program. We did not consider the number of Family Health programs in each health unit in this study. Unlike the units within the FHS in which a multi-professional NASF team is employed, traditional units are not composed of diverse professional teams and are based on care provided in medical consultation. The primary sampling frame included the 42,486 primary health care units in the Brazilian Ministry of Health registry (Cadastro Nacional de Estabelecimentos de Saúde - CNES. http://cnes.datasus.gov.br, accessed on $02 / \mathrm{Jan} / 2011$ ). The sample consisted of 1,600 randomly selected primary health care units covering all regions of the country. The sample was representative of all Brazilian health units (Table 1). For the sample size, a prevalence of $50 \%$ of health units with physical activity programs was considered, and a four percentage points error; at least 600 health units were required to detect a meaningful difference, and our sample selection surpassed this number.

The interviews were carried out by six, trained interviewers from the Federal University of Pelotas (UFPel). The maximum duration of each interview was 40 minutes. Data collection occurred between January and July 2011. Coordinators were asked about physical activity interventions because not all units have a specific professional for physical activity, and coordinators will likely have an overview about all health promotion strategies in their units. The coordinators of all selected units were invited to attend an interview, and then to contact a doctor, nurse, or community health worker drawn from their respective facilities. For this study, we used only data related to the health unit coordinators.

Coordinators responded to an open-ended and multiple-choice questionnaire of yes or no questions related to the operation of health facilities, the presence or absence of interventions aimed at increasing physical activity, and the characteristics of such programs. For this study we analyzed only the units that had some type of intervention for physical activity, subject to the absence or presence of NASF in the city, and by region of Brazil. Other variables included: all types of physical activity programs, frequency and duration of activities, a professional that supervised the activities, the presence of extra events, activities for school children, time of day the events occurred, sites where the physical activity took place and the perceived quality of the programs.

All data were entered into the version 3.1 of the Epidata program (Epidata Assoc., Odense, Denmark) and then transferred to Stata, version 12.0 (Stata Corp., College Station, USA). An analysis of the consistency and missing values was performed. We carried out a descriptive analysis using absolute and relative frequencies. These proportions were described according to the stratification. This study was approved by the Ethics Research Committee of the School of Physical Education/UFPel (n. 16154).

\section{Results}

The coordinators response rate was $78 \%$. Of the 1,600 primary care units initially contacted, 1,251 participated in the survey, of which 495 (39.5\%) reported the existence of physical activity interventions. Out of the 1,251 primary care units, a

Table 1

Strategy sample for representativity of health care units (UBS) in Brazil

\begin{tabular}{|c|c|c|c|c|c|c|}
\hline Regions & Cities & $\begin{array}{c}\text { Cities/ } \\
\text { Region (\%) }\end{array}$ & UBS/Region & $\begin{array}{c}\text { UBS/ } \\
\text { Region (\%) }\end{array}$ & $\begin{array}{l}\text { Units } \\
\text { interviewed }\end{array}$ & $\begin{array}{c}\text { Response } \\
\text { rate (\%) }\end{array}$ \\
\hline South & 229 & 16.2 & 250 & 15.6 & 227 & 90.8 \\
\hline Southeast & 400 & 28.2 & 473 & 29.6 & 452 & 95.5 \\
\hline Central West & 113 & 7.3 & 110 & 6.8 & 81 & 73.6 \\
\hline Northeast & 567 & 40.0 & 629 & 39.3 & 395 & 62.7 \\
\hline North & 118 & 8.3 & 138 & 8.6 & 96 & 69.5 \\
\hline Total & 1,417 & 100.0 & 1,600 & 100.0 & 1,251 & 78.1 \\
\hline
\end{tabular}


total of $60.7 \%$ were FHS, $23.6 \%$ traditional, and $15.7 \%$ mixed.

Table 2 shows the comparison of units with and without physical activity interventions according to the presence or absence of NASF in the city and regions of Brazil. Units without NASF (32.8\%) had less physical activity interventions compared to units with NASF $(50 \%)(\mathrm{p}<0.001)$. Among the units with physical activity referral interventions, the largest proportions were found in the Southeast $(50.3 \%)$ region $(\mathrm{p}<0.001)$ and the smallest proportion in the North $(21 \%)$. In the cities with NASF, the prevalence of health units with physical activity interventions distributed by region were $41.0 \%$ in the Northeast, $34 \%$ in the Southeast, $12.3 \%$ in the South, $9.4 \%$ in the Central West and $3.3 \%$ in the North.

Table 3 presents the absolute and relative frequency of the operating characteristics for all units. Most coordinators reported more than one type of physical activity intervention. In total, 1,762 types of intervention were found. Walking groups was the most frequent type of physical activity intervention (81.1\%). The most common weekly frequency for physical activity programs was once a week (33.1\%), lasting from 30 minutes to an hour (51.4\%) (Table 3). Physical education professionals were responsible for overseeing physical activity programs in $48.8 \%$ of primary health units. In a large portion of units, other health professionals (physicians, nutritionists, and physiotherapists) also guided activities. Approximately $60 \%$ of the units performed additional activities in the form of lectures and courses (45.5\%). Most units did not carry out activities for school children (81.8\%). Most activities oc- curred within the health unit (55.5\%), followed by churches/associations/community centers (53.1\%) and sidewalks/streets (43.7\%). Pools (7.3\%) and bike paths (3.9\%) were less frequently cited as spaces for physical activity interventions. The proportion of coordinators that considered the quality of the primary care unit's physical structure to be good/adequate was $52.1 \%$.

The characteristics of the physical activity interventions according to the presence or absence of NASF in the city are also presented in Table 3. Similar proportions were found in the types of physical activity offered in both groups, except for "stretching and relaxation" activities (> 10\% difference). The most common activities were walking and "stretching and relaxation" exercises (80.6\% and $71 \%$, respectively) among units with NASF. The least frequent activity was capoeira $(<3 \%$ in units with and without NASF). The average duration of most classes was 30-60 minutes in $57.5 \%$ of NASF units versus $49.2 \%$ in units without NASF. In $54.5 \%$ of NASF units, physical education professionals supervised physical activity versus $44 \%$ in units without NASF. A large proportion of other professionals were responsible for this supervision in both situations (presence $=52 \%$ and absence $=45.2 \%$ ). Additional activities were most often held in units without NASF in the city $(61.9 \%)$, and physical activity lectures/courses were more prevalent (47.6\%). Approximately $84.8 \%$ and $80.4 \%$ of units with or without NASF in the city have not developed activities for school children. Among the units that were developing these activities, $64.8 \%$ were performed during the week, most of them outside of school hours for the units with NASF and $61.9 \%$

\begin{tabular}{|c|c|c|c|}
\hline & \multicolumn{2}{|c|}{ Physical activity intervention } & \multirow[t]{2}{*}{$\mathrm{p}$-value * } \\
\hline & $\mathrm{n}$ & $\%$ & \\
\hline NASF in the city & & & $<0.001$ \\
\hline No & 201 & 32.8 & \\
\hline Yes & 212 & 50.0 & \\
\hline Region & & & $<0.001$ \\
\hline Southeast & 200 & 50.6 & \\
\hline Northeast & 155 & 34.3 & \\
\hline North & 17 & 21.0 & \\
\hline South & 79 & 34.8 & \\
\hline Central West & 44 & 45.8 & \\
\hline
\end{tabular}

* Chi-square test. 
Table 3

Characteristics of local physical activity interventions in health facilities according to presence or absence of Multidisciplinary Primary Care Teams (NASF) in the city. Brazil, $2012(\mathrm{~N}=495)$.

\begin{tabular}{|c|c|c|c|c|c|c|}
\hline \multirow[t]{2}{*}{ Variables } & \multicolumn{2}{|c|}{ Total } & \multicolumn{2}{|c|}{$\begin{array}{l}\text { Presence of NASF * } \\
\text { in the city * }\end{array}$} & \multicolumn{2}{|c|}{$\begin{array}{c}\text { Absence of NASF } \\
\text { in the city * }\end{array}$} \\
\hline & $\mathrm{n}$ & $\%$ & $\mathrm{n}$ & $\%$ & $\mathrm{n}$ & $\%$ \\
\hline \multicolumn{7}{|l|}{ Types of physical activity $(n=495 / 1,762) \star *$} \\
\hline Physical assessment & 323 & 67.1 & 122 & 61.9 & 149 & 72.3 \\
\hline Walking group & 397 & 81.1 & 162 & 80.6 & 171 & 81.8 \\
\hline External physical activity (Lia-Gong, Tai chi chuan) & 26 & 13.6 & 9 & 11.6 & 13 & 15.6 \\
\hline Stretching and relaxation exercises & 379 & 77.3 & 142 & 71.0 & 171 & 81.4 \\
\hline 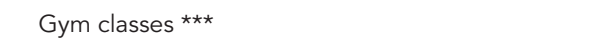 & 202 & 41.6 & 78 & 39.0 & 93 & 44.7 \\
\hline Weight lifting & 35 & 7.2 & 19 & 9.5 & 13 & 6.2 \\
\hline Touring activities \# & 200 & 41.3 & 83 & 41.5 & 88 & 42.5 \\
\hline Communication & 117 & 24.2 & 42 & 21.1 & 50 & 24.0 \\
\hline Capoeira\#\# & 18 & 3.7 & 6 & 2.9 & 6 & 2.8 \\
\hline Team sports (soccer, volleyball, handball, futsal) & 65 & 13.4 & 30 & 14.9 & 25 & 12.0 \\
\hline Popular games & 90 & 18.7 & 37 & 18.7 & 39 & 19.0 \\
\hline Dance & 132 & 27.3 & 58 & 29.0 & 47 & 23.0 \\
\hline Treadmill cycling & 28 & 5.7 & 10 & 5.0 & 15 & 7.1 \\
\hline \multicolumn{7}{|l|}{ Weekly frequency of physical activity $(n=449) \# \#$} \\
\hline $1 /$ week & 149 & 33.1 & 63 & 33.5 & 64 & 33.5 \\
\hline $2 /$ week & 132 & 29.4 & 62 & 32.9 & 49 & 25.6 \\
\hline 3/week & 102 & 22.7 & 38 & 20.2 & 48 & 25.1 \\
\hline 4/week or more & 66 & 14.7 & 25 & 13.2 & 30 & 15.7 \\
\hline \multicolumn{7}{|l|}{ Average duration of activities $(n=448) \# \#$} \\
\hline Less than 30 minutes & 5 & 1.1 & 2 & 1.0 & 3 & 1.4 \\
\hline 30 minutes to 1 hour & 251 & 51.4 & 114 & 57.5 & 103 & 49.2 \\
\hline More than 1 hour & 232 & 48.5 & 82 & 41.4 & 103 & 49.2 \\
\hline \multicolumn{7}{|l|}{ Time of day activities are offered $(n=488) \# \# \#$} \\
\hline Morning & 429 & 87.9 & 176 & 88.0 & 183 & 87.6 \\
\hline Afternoon & 251 & 51.5 & 107 & 53.8 & 106 & 50.7 \\
\hline Night & 24 & 4.9 & 11 & 5.5 & 11 & 5.3 \\
\hline \multicolumn{7}{|l|}{ Professional who guides physical activity $(n=491) \# \#$} \\
\hline Physical education professional & 240 & 48.8 & 88 & 44.0 & 115 & 54.5 \\
\hline Doctor & 35 & 7.1 & 13 & 6.5 & 14 & 6.6 \\
\hline Nutritionist & 17 & 3.4 & 8 & 4.0 & 5 & 2.3 \\
\hline Social worker & 11 & 2.2 & 4 & 2.0 & 3 & 1.4 \\
\hline Physical therapist & 87 & 17.6 & 35 & 17.5 & 39 & 18.4 \\
\hline Other & 75 & 50.2 & 104 & 52.0 & 96 & 45.2 \\
\hline \multicolumn{7}{|l|}{ Additional activities $(n=490)$} \\
\hline No & 196 & 40.0 & 84 & 42.0 & 80 & 38.1 \\
\hline Yes & 294 & 60.0 & 116 & 58.0 & 130 & 61.9 \\
\hline \multicolumn{7}{|l|}{ Types of additional activities $(n=201)$} \\
\hline Lectures/Courses & 163 & 45.5 & 59 & 41.2 & 72 & 47.6 \\
\hline Play/Games & 13 & 6.2 & 3 & 3.4 & 10 & 11.2 \\
\hline Walking groups campaigns & 18 & 8.4 & 10 & 10.6 & 6 & 7.0 \\
\hline Big classes § & 7 & 3.4 & 5 & 5.6 & 1 & 1.2 \\
\hline
\end{tabular}

(continues) 
Table 3 (continued)

\begin{tabular}{|c|c|c|c|c|c|c|}
\hline \multirow[t]{2}{*}{ Variables } & \multicolumn{2}{|c|}{ Total } & \multicolumn{2}{|c|}{$\begin{array}{c}\text { Presence of NASF } \\
\text { in the city * }\end{array}$} & \multicolumn{2}{|c|}{$\begin{array}{c}\text { Absence of NASF } \\
\text { in the city }\end{array}$} \\
\hline & $\mathbf{n}$ & $\%$ & $\mathbf{n}$ & $\%$ & $\mathbf{n}$ & $\%$ \\
\hline \multicolumn{7}{|c|}{ Activities developed for schools $(n=489)$} \\
\hline None & 400 & 81.8 & 168 & 85.0 & 169 & 80.5 \\
\hline Playground & 2 & 0.5 & 0 & 0.0 & 1 & 0.5 \\
\hline Classroom & 26 & 5.3 & 9 & 4.5 & 14 & 6.6 \\
\hline Lectures & 31 & 6.3 & 9 & 4.5 & 14 & 6.6 \\
\hline Others & 30 & 6.1 & 12 & 6.0 & 12 & 5.8 \\
\hline \multicolumn{7}{|c|}{ Period when activity occurs in school $(n=91)$} \\
\hline Weekend & 2 & 2.2 & 0 & 0.0 & 1 & 2.3 \\
\hline Outside of school hours & 45 & 49.4 & 11 & 35.4 & 26 & 61.9 \\
\hline Other & 12 & 13.1 & 20 & 64.8 & 15 & 35.7 \\
\hline
\end{tabular}

* "Do not know/Did not answer" were not considered in the statistical analysis;

** The respondents could report more than one type of intervention in each health unit;

*** Recreational, aerobic and neuromuscular exercise distributed in the same class;

\# Small trip or walking in a group to a park or other place of leisure;

\#\# Typical Brazilian martial art from the Northeast region which mixes fighting, dance, popular culture and music;

\#\#\# The respondents chose one of the reported interventions of physical activity;

$\S$ A big exercise class in a public space involving a large number of people that is used as a strategy to attract other participants.

Note: maximum number of missing answers $=47$.

for units without NASF in the city. Table 4 shows the characteristics of the places used for physical activity interventions. As it relates to where the physical activity was performed, the proportions were similar between units with and without NASF, most of which took place at the health unit $(53.2 \%$ and $57.3 \%)$, churches/community centers (51.2\% and 53.3\%), and sidewalks/streets ( $45.2 \%$ and $46.7 \%$ ), respectively. Bike paths were less commonly used for physical activity interventions in both cases (2.3\% and 5.5\%). A higher proportion of coordinators from units with NASF reported good/adequate quality structures compared with those from units without NASF $(53.5 \%$ and $49.7 \%$ ).

The characteristics of the interventions by region are presented in Table 5. The most common type of physical activity reported was walking groups from those in the Central West region $(93 \%)$. The North region presented the lowest frequency of physical activity interventions. In addition to these activities, the North had the highest frequency of stretching/relaxation $(82.4 \%)$, while the Northeast had the highest proportions of physical assessments $(70.7 \%)$ and fitness classes (49.7\%). The highest and lowest weekly frequencies of physical activities were twice a week in the North (46.2\%) and four times per week in the Central West (5.1\%). Few units from all regions had classes lasting less than 30 minutes. The Central West region had the highest proportion of units with classes lasting 30-60 minutes (63.6\%), while most of the lessons in the Northeast took over an hour $(57.5 \%)$. The majority of classes were held in the morning in all regions, most frequently in the North $(94.1 \%)$. The highest proportion of afternoon classes was reported in the South $(66.7 \%)$. Physical education professionals were responsible for guiding physical activity in most regions, especially in the South $(57.7 \%)$. In the North region other professionals were mostly engaged in physical activity promotion (70.6\%). This region was also where more extra events occurred $(62.7 \%)$, mostly in the form of lectures/courses (51.7\%). The regions reporting no physical activity programs for children with the highest and lowest proportion were the Southeast (85.4\%) and South (75\%). Most activities happened outside of school hours (75\%). Table 6 depicts the perceptions of coordinators as to where activities take place by region. In the North, activities occurred more frequently on sidewalks/streets (80\%) and walking tracks (60\%). In the Southeast, activities occurred more frequently in the health unit (50\%) and in squares and parks $(47.6 \%)$. The rating of physical spaces as good/adequate by coordinators ranged from $35 \%$ (Central West) to $60 \%$ (North). 
Table 4

Characteristics of the places for physical activity interventions in health units according to presence or absence of Multidisciplinary Primary Care Teams (NASF) in the city. Brazil, $2012(\mathrm{~N}=495)$.

\begin{tabular}{|c|c|c|c|c|c|c|}
\hline \multirow[t]{2}{*}{ Variables } & \multicolumn{2}{|c|}{ Total * } & \multicolumn{2}{|c|}{$\begin{array}{l}\text { Presence of NASF } \\
\text { in the city * }\end{array}$} & \multicolumn{2}{|c|}{$\begin{array}{l}\text { Absence of NASF } \\
\text { in the city }\end{array}$} \\
\hline & $\mathrm{n}$ & $\%$ & $\mathrm{n}$ & $\%$ & $\mathrm{n}$ & $\%$ \\
\hline \multicolumn{7}{|l|}{ Area where physical activities are performed } \\
\hline \multicolumn{7}{|l|}{$(n=495 / 1,291) * \star$} \\
\hline Health unit & 272 & 55.5 & 106 & 53.2 & 121 & 57.3 \\
\hline Churches, community centers and associations & 260 & 53.1 & 102 & 51.2 & 112 & 53.3 \\
\hline Plaza/Park & 223 & 45.6 & 102 & 38.7 & 84 & 37.6 \\
\hline Streets/Sidewalks & 214 & 43.7 & 93 & 46.7 & 95 & 45.2 \\
\hline Gymnasium & 115 & 23.2 & 57 & 28.6 & 45 & 21.4 \\
\hline Jogging track & 83 & 16.9 & 35 & 17.5 & 32 & 15.2 \\
\hline Gym & 69 & 14.1 & 26 & 13.1 & 33 & 15.7 \\
\hline Pool & 36 & 7.3 & 17 & 8.5 & 15 & 7.1 \\
\hline Bike paths & 19 & 3.9 & 11 & 5.5 & 5 & 2.3 \\
\hline \multicolumn{7}{|l|}{ Quality of structures $(n=486)$ * } \\
\hline Majority are good/adequate & 249 & 51.2 & 106 & 53.5 & 102 & 49.5 \\
\hline Some are adequate, some are not & 156 & 32.1 & 59 & 29.8 & 71 & 34.4 \\
\hline The majority are bad/inadequate & 81 & 16.7 & 33 & 16.6 & 33 & 15.7 \\
\hline
\end{tabular}

* "Does not know/Did not answer" were not considered in the statistical analysis;

** The respondents could report more than one place for the physical activity intervention.

Note: maximum number of missing answers (Does not know/Did not answer) $=91$.

Table 5

Characteristics of physical activity interventions in the health unit by region. Brazil $2012(\mathrm{~N}=495)$.

\begin{tabular}{|c|c|c|c|c|c|c|c|c|c|c|}
\hline \multirow[t]{2}{*}{ Variables } & \multicolumn{2}{|c|}{ Southeast * } & \multicolumn{2}{|c|}{ Northeast * } & \multicolumn{2}{|c|}{ North * } & \multicolumn{2}{|c|}{ South * } & \multicolumn{2}{|c|}{ Central West * } \\
\hline & $\mathrm{n}$ & $\%$ & $\mathrm{n}$ & $\%$ & $\mathrm{n}$ & $\%$ & $\mathrm{n}$ & $\%$ & $\mathrm{n}$ & $\%$ \\
\hline \multicolumn{11}{|l|}{$\begin{array}{l}\text { Types of physical activity and } \\
\text { actions offered }(n=495 / 1,762) * *\end{array}$} \\
\hline Walking group & 158 & 80.2 & 121 & 79.1 & 15 & 88.2 & 63 & 79.7 & 40 & 93.0 \\
\hline $\begin{array}{l}\text { Stretching and relaxation } \\
\text { exercises }\end{array}$ & 150 & 76.1 & 123 & 79.9 & 14 & 82.4 & 59 & 74.7 & 33 & 76.7 \\
\hline Physical assessment & 135 & 70.7 & 106 & 69.7 & 11 & 64.7 & 49 & 62.0 & 22 & 52.4 \\
\hline Gym classes *** & 97 & 49.7 & 51 & 33.8 & 6 & 35.3 & 38 & 48.1 & 10 & 23.3 \\
\hline Touring activities \# & 82 & 42.1 & 62 & 41.1 & 7 & 41.2 & 33 & 42.3 & 16 & 37.2 \\
\hline Dance & 44 & 22.6 & 47 & 31.1 & 8 & 47.7 & 23 & 29.9 & 10 & 23.8 \\
\hline Communication & 41 & 21.1 & 42 & 27.6 & 4 & 23.5 & 21 & 27.3 & 9 & 20.9 \\
\hline Popular games & 34 & 17.9 & 36 & 23.7 & 4 & 23.5 & 11 & 14.3 & 5 & 11.6 \\
\hline $\begin{array}{l}\text { Team sports (soccer, volleyball, } \\
\text { handball, futsal) }\end{array}$ & 23 & 11.9 & 26 & 17.1 & 3 & 17.6 & 9 & 11.4 & 4 & 9.3 \\
\hline Weight lifting & 15 & 7.8 & 8 & 5.3 & 3 & 18.8 & 7 & 8.9 & 2 & 4,7 \\
\hline $\begin{array}{l}\text { Alternative physical activity } \\
\text { practices }\end{array}$ & 11 & 17.5 & 11 & 16.4 & 0 & 0.0 & 1 & 2.9 & 2 & 10.0 \\
\hline Treadmill cycling & 9 & 4.6 & 8 & 5.2 & 1 & 5.9 & 6 & 7.6 & 4 & 9.3 \\
\hline Capoeira \#\# & 5 & 2.6 & 11 & 7.2 & 0 & 0.0 & 1 & 1.3 & 1 & 2.3 \\
\hline
\end{tabular}

(continues) 
Table 5 (continued)

\begin{tabular}{|c|c|c|c|c|c|c|c|c|c|c|}
\hline \multirow[t]{2}{*}{ Variables } & \multicolumn{2}{|c|}{ Southeast * } & \multicolumn{2}{|c|}{ Northeast * } & \multicolumn{2}{|c|}{ North * } & \multicolumn{2}{|c|}{ South * } & \multicolumn{2}{|c|}{ Central West * } \\
\hline & $\mathbf{n}$ & $\%$ & $\mathbf{n}$ & $\%$ & $\mathbf{n}$ & $\%$ & $\mathbf{n}$ & $\%$ & $\mathbf{n}$ & $\%$ \\
\hline \multicolumn{11}{|l|}{ Weekly frequency of physical } \\
\hline \multicolumn{11}{|l|}{ activity $(n=449) \# \# \#$} \\
\hline 1/week & 47 & 24.5 & 54 & 42.5 & 4 & 30.8 & 29 & 37.2 & 15 & 38.5 \\
\hline 2/week & 64 & 33.3 & 29 & 22.8 & 6 & 46.2 & 21 & 26.9 & 12 & 30.8 \\
\hline 3/week & 45 & 23.4 & 26 & 20.5 & 2 & 15.4 & 19 & 24.4 & 10 & 25.6 \\
\hline 4/week or more & 36 & 18.8 & 18 & 14.2 & 1 & 7.7 & 9 & 11.5 & 2 & 5.1 \\
\hline \multicolumn{11}{|l|}{ Average duration of activities } \\
\hline \multicolumn{11}{|l|}{$(n=448) \# \#$} \\
\hline Less than 30 minutes & 1 & 0.5 & 3 & 2.0 & 0 & 0.0 & 1 & 1.3 & 0 & 0.0 \\
\hline 30 minutes to 1 hour & 110 & 56.4 & 62 & 40.5 & 8 & 47.1 & 4 & 54.4 & 28 & 63.6 \\
\hline More than 1 hour & 84 & 43.1 & 88 & 57.5 & 9 & 52.9 & 35 & 44.3 & 16 & 36.4 \\
\hline \multicolumn{11}{|l|}{ Time of day $(n=488) \# \#$} \\
\hline Morning & 186 & 93.5 & 125 & 85.4 & 16 & 94.1 & 58 & 74.4 & 40 & 93.0 \\
\hline Afternoon & 88 & 44.2 & 88 & 58.7 & 6 & 35.3 & 52 & 66.7 & 17 & 39.5 \\
\hline Night & 13 & 6.5 & 3 & 2.0 & 0 & 0.0 & 7 & 9 & 1 & 2.3 \\
\hline \multicolumn{11}{|l|}{ Profession guiding physical activity } \\
\hline \multicolumn{11}{|l|}{$(n=491) \# \#$} \\
\hline Other & 97 & 48.5 & 73 & 47.7 & 12 & 70.6 & 41 & 51.9 & 24 & 55.8 \\
\hline Physical education professional & 95 & 47.5 & 83 & 54.2 & 3 & 17.6 & 45 & 57.7 & 14 & 32.6 \\
\hline Physical therapist & 44 & 22.0 & 11 & 7.1 & 5 & 29.4 & 15 & 19.0 & 12 & 27.9 \\
\hline Doctor & 12 & 6.0 & 6 & 3.9 & 1 & 5.9 & 9 & 11.5 & 7 & 16.3 \\
\hline Nutritionist & 8 & 4.0 & 4 & 2.6 & 0 & 0.0 & 4 & 5.1 & 1 & 2.3 \\
\hline Social worker & 3 & 1.5 & 4 & 2.6 & 0 & 0.0 & 3 & 3.8 & 1 & 2.3 \\
\hline \multicolumn{11}{|l|}{ Additional activities ( $n=490)$} \\
\hline No & 78 & 39.4 & 57 & 37.3 & 7 & 41.2 & 30 & 38.0 & 24 & 55.8 \\
\hline Yes & 120 & 60.6 & 96 & 62.7 & 10 & 58.8 & 49 & 62.0 & 19,0 & 44.2 \\
\hline \multicolumn{11}{|l|}{ Types of additional activities } \\
\hline \multicolumn{11}{|l|}{$(n=201)$} \\
\hline Lectures/Courses & 59 & 43.1 & 60 & 51.7 & 7 & 50.0 & 28 & 48.3 & 9 & 27.3 \\
\hline Walking groups & 6 & 7.1 & 6 & 9.7 & 0 & 0.0 & 0 & 0.0 & 0 & 0.0 \\
\hline Play and games & 4 & 4.9 & 7 & 11.7 & 0 & 0.0 & 2 & 6.3 & 0 & 0.0 \\
\hline Large classes $\S$ & 3 & 3.7 & 3 & 5.1 & 0 & 0.0 & 0 & 0.0 & 1 & 4.0 \\
\hline \multicolumn{11}{|l|}{ Activities developed for schools } \\
\hline \multicolumn{11}{|l|}{$(n=489)$} \\
\hline None & 70 & 85.4 & 51 & 83.6 & 4 & 80.0 & 12 & 75.0 & 15 & 71.4 \\
\hline Classroom & 5 & 6.1 & 4 & 6.6 & 0 & 0.0 & 1 & 6.3 & 2 & 9.5 \\
\hline Lectures & 4 & 4.9 & 3 & 4.5 & 0 & 0.0 & 1 & 6.3 & 2 & 9.5 \\
\hline Others & 3 & 3.7 & 3 & 4.5 & 1 & 20.0 & 2 & 12.5 & 2 & 9.5 \\
\hline Playground & 0 & 0.0 & 0 & 0.0 & 0 & 0.0 & 0 & 0.0 & 0 & 0.0 \\
\hline \multirow{2}{*}{\multicolumn{11}{|c|}{$\begin{array}{l}\text { Period when activity occurs in } \\
\text { school }(n=91)\end{array}$}} \\
\hline & & & & & & & & & & \\
\hline Outside of school hours & 6 & 50.0 & 6 & 54.5 & 1 & 100 & 3 & 75.0 & 3 & 50.0 \\
\hline Other & 5 & 41.7 & 5 & 45.5 & 0 & 0.0 & 1 & 25.0 & 3 & 50.0 \\
\hline Weekend & 1 & 8.3 & 0 & 0.0 & 0 & 0.0 & 0 & 0.0 & 0 & 0.0 \\
\hline
\end{tabular}

* "Does not know/Did not answer" were not considered in the statistical analysis;

** The respondents could report more than one type of intervention in each health unit;

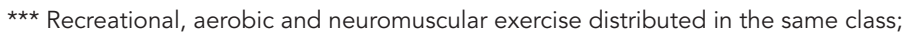

\# Small trip or walking in a group to a park or other place of leisure;

\#\# Typical Brazilian martial art from the Northeast region which mixes fighting, dance, popular culture and music;

\#\#\# The respondents chose one of the reported interventions of physical activity;

$\S$ A big exercise class in a public space involving many people that is used as a strategy to attract other participants.

Note: maximum number of missing answers $=41$. 
Characteristics of the places for physical activity interventions according to region. Brazil, $2012(N=495)$.

\begin{tabular}{|c|c|c|c|c|c|c|c|c|c|c|}
\hline \multirow[t]{2}{*}{ Variables } & \multicolumn{2}{|c|}{ Southeast } & \multicolumn{2}{|c|}{ Northeast } & \multicolumn{2}{|c|}{ North } & \multicolumn{2}{|c|}{ South } & \multicolumn{2}{|c|}{ Central West } \\
\hline & $\mathrm{n}$ & $\%$ & $\mathrm{n}$ & $\%$ & $\mathrm{n}$ & $\%$ & $\mathrm{n}$ & $\%$ & $\mathrm{n}$ & $\%$ \\
\hline \multicolumn{11}{|c|}{$\begin{array}{l}\text { Area where physical activities are performed } \\
(n=495 / 474) *\end{array}$} \\
\hline Health unit & 41 & 50.0 & 28 & 45.2 & 2 & 40.0 & 7 & 41.2 & 8 & 40.0 \\
\hline Plaza/Park & 39 & 47.6 & 28 & 38.7 & 1 & 20.0 & 7 & 41.2 & 13 & 65.0 \\
\hline $\begin{array}{l}\text { Churches, community centers and } \\
\text { associations }\end{array}$ & 40 & 48.8 & 27 & 43.5 & 2 & 40.0 & 11 & 64.7 & 12 & 60.0 \\
\hline Streets/Sidewalks & 27 & 32.9 & 27 & 43.5 & 4 & 80.0 & 5 & 29.4 & 13 & 65.0 \\
\hline Pool & 7 & 8.5 & 7 & 11.3 & 1 & 20.0 & 0 & 0.0 & 1 & 5.0 \\
\hline Bike paths & 5 & 6.1 & 5 & 8.1 & 0 & 0.0 & 0 & 0.0 & 1 & 5.0 \\
\hline Gym & 10 & 12.2 & 9 & 14.5 & 1 & 20.0 & 2 & 11.8 & 2 & 10.0 \\
\hline Walking track & 10 & 12.2 & 14 & 22.6 & 3 & 60.0 & 3 & 17.6 & 5 & 25.0 \\
\hline Gymnasium & 23 & 28.0 & 13 & 21.0 & 1 & 20.0 & 3 & 17.6 & 6 & 30.0 \\
\hline \multicolumn{11}{|l|}{ Quality of structures $(n=483)$ *夫 } \\
\hline Majority are good/adequate & 94 & 47.7 & 76 & 51.3 & 9 & 52.9 & 47 & 59.4 & 21 & 50 \\
\hline Some are adequate, some are not & 67 & 34.1 & 47 & 31.7 & 5 & 29.4 & 20 & 25.3 & 16 & 38.1 \\
\hline The majority are bad/inadequate & 36 & 18.2 & 25 & 16.8 & 3 & 17.6 & 12 & 15.1 & 5 & 11.9 \\
\hline
\end{tabular}

* The respondents could report more than one place for physical activity intervention;

** "Does not know/Did not answer" were not considered in the statistical analysis.

Note: maximum number of missing answers (Does not know/Did not answer) $=21$.

\section{Discussion}

This is the first study to investigate physical activity interventions within the SUS in Brazil using a nationally representative sample. Data from this study showed that four out of ten primary care units offered physical activity promotion programs, while units with NASF in the city had a larger proportion of physical activity interventions. We also found more physical education professionals supervising physical activities in units in cities without NASF. This finding was somewhat unexpected given that NASF policies include physical education professionals and that physical activity interventions are anticipated in cities with NASF. This might be due to the fact that NASF guidelines were created only three years ago 32 and the presence of physical activity programs was independent of NASF. In addition, the expansion of the NASF started exactly when the data collection happened and a general question was asked about the presence of NASF in the city, thus we do not know exactly if the selected health units were linked with the NASF team at that time. As such, there was a limitation to understanding the relationship between the presence of NASF and the existence of physical activity interventions.
Regarding the types of physical activity programs offered, walking groups were reported to be the most common activity in our study. These data are in line with the history of physical activity in the Brazilian primary care system. Walking groups have been used as a strategy for promoting health among high-risk groups (e.g. diabetes, hypertension) and have been in place since the 1990s 7 . The presence of these groups has been stable 7 and has been supported by public policies that encourage physical activity in Brazil, especially the National Policy for the Promotion of Health $8,12,32$. This policy is characterized by an equity incentive, social participation, the capacity building of health professionals, and the dissemination and exchange of successful practices. The policy has guided actions of primary health care around the country, which may have contributed to the maintenance of these groups 22 .

However, there was a wide range of variation for the functional characteristics of health facilities according to different regions of the country. This fact can be explained by the socioeconomic and cultural differences between regions, which according to some studies determine the performance of actions in the primary health care system 33,34 . The Northeast region was noted for having more structured interventions and frequent 
physical assessments, offering more physical activities, and having a greater number of physical education professionals guiding activities. In line with these data, the health promotion network of the SUS, funded by the Brazilian Ministry of Health after 2005, underwent a large expansion in the Southwest and Northeast regions of the country 7 . In addition, the Northeast was the first region in the country in which the FHS was implemented, and involved the expansion of strategic actions in the community 10 . Factors such as climate, average temperatures and work organization may explain the difference in results between regions, regarding the time of the day the classes were offered (morning or afternoon).

Physical activity recommendations to improve health outcomes in adult populations call for at least 150 minutes per week of moderate intensity physical activity, 75 weekly minutes of vigorous activity, or an equivalent combination, in addition to strength training and stretching activities twice per week 35 . These recommendations have also been recommended in health promotion policies in Brazil. Offering physical activity in primary care settings is very relevant since it benefits vulnerable populations that need access to health promotion and non-communicable disease control. Findings from this study showed that most units do not offer the minimum weekly volume of physical activity required according to international recommendations (at least 150 minutes of moderate physical activity per week) 35 . However, achieving physical activity recommendations is not the primary goal of interventions in primary care settings. They can also include strategies to change behavior towards physical activities and awareness about the health benefits of physical activity, which are in accordance with the health promotion policies established in this setting. In addition, units do offer events through lectures and courses that can lead to greater awareness and knowledge about the importance of achieving physical activity guidelines for health benefits. As a consequence, it is possible that individuals would feel better prepared and encouraged to engage in additional bouts of physical activity and exercise outside of the referral system and health facilities, thus the role of primary care in increasing physical activity levels would be fulfilled through outreach programs and activities 13,17,36.

This study showed that physical education professionals led most of the physical activity programs. Similar findings have been reported by the Physical Activity National Network of Brazil, which found that in 1,500 municipalities receiving funding for physical activity interventions, physical education professionals directed $91.5 \%$ of the programs 7. Physical education has been recognized as a health profession in Brazil since 1998 and has been identified in the proposed policies as part of the NASF team 11,12 . In recent years, physical education professionals have increasingly acted in the context of prevention and control of non-communicable diseases (NCD). In terms of physical activity, the data from this study also revealed that other health professionals have collaborated significantly in this process, mainly in the North. Among these, users specifically have praised the community health worker as the most outstanding professional category, possibly due to the proximity of their work with the community 37 . Teamwork within primary care is recommended in the National Primary Health Care guidelines 11. The importance of conducting multidisciplinary work in this context has stimulated a collective effort from the entire team to solve the most common problems and prioritize high-risk groups through educational activities and the implementation of health promotion strategies which may help explain our results $12,38,39$. In addition to physicians and other primary care providers, physical education professionals, other exercise specialists and community health workers are therefore a very useful and untapped resource for the promotion of physical activity in primary care systems. They also have a role to play in providing links to community resources, as advocated by global programs such as the Exercise is Medicine initiative 40,41.

The data also showed that most units do not offer physical activities for school children. In a systematic review of physical activity interventions in Latin America, Hoehner et al. 42 and Lobelo et al. 43 reported that physical education classes in elementary school are effective in increasing physical activity levels among children. Furthermore, school-based and health care based interventions have also been shown to be effective for the prevention and management of obesity in Latin America and among Latinos in the US 44,45 . This highlights the need for encouraging the development and implementation of physical activity referral programs for children and young people by ensuring coordination between the primary health care system and schools.

With regard to the quality of the program's infrastructure, Bauman et al. 46 suggest that environmental factors may determine more effective results in physical activity programs. Inadequate facilities may be an important reason for the lack of programs in these regions. The evaluation results on the physical characteristics of the sites were different between regions of the country in this study; 40 to $65 \%$ of coordinators are dissatis- 
fied with the quality of the facilities where physical activity programs are offered.

There are limitations to be noted in this study. Some of these are intrinsic to the research which involved a telephone survey and used questionnaires. These methods included comprehensive questions that do not allow for more in depth information with regard to some important issues and may introduce desirability or other biases associated with self-reports. We did not develop a method of data validation, which limits the interpretation of our results. Considering that physical activity interventions can occur in many ways, it was not possible to identify, for example, if the physical activity programs reported were structured, had supervised classes or details on physical activity counseling given by the health professionals. This study was also unable to conclude if weekly frequency of programs which offered classes more than four times per week was referring to classes on the same day or different days. Since the coordinator reported more than one type of physical activity intervention, we were not able to know which one they were referring to for example the frequency or duration of the classes. In addition, it was not possible to know if the facilities in the primary centers were created specifically for physical activities or if it was necessary to adapt rooms, parking areas or corridors in the units. Further studies should explore these issues in more depth through qualitative studies and objective assessments 47 . Lastly, it is possible that the coordinator's report on the number of primary health care units with physical activity referral interventions may have been overestimated, or some of them might have been carried out without any funding. Data from the Brazilian Ministry of Health reported that about $17 \%$ of municipalities were awarded funding for physical activity interventions in 2010, around half the figure reported by coordinators in this study 48 . In addition, from all selected municipalities for this study, $26.6 \%$ had funding from the Ministry of Health to carry out a physical activity intervention. The coordinators probably considered counseling, lectures, education groups, and campaigns about physical activity as physical activity interventions.

There are limitations when it comes to comparing our data with other international studies because the link with the health care system is unique in Brazil. In addition, most of the international interventions in primary care settings use physical activity referral programs 13,17,19,25,36 and studies are focused on the effectiveness of physical activity interventions instead of describing their characteristics. The effectiveness of physical activity interventions is determined using supervised classes, personal or telephone counseling, education activities and pedometer use $18,19,25,36$. There is widespread evidence of the evaluation of physical activity interventions in Brazil 7. Although a formal evaluation of effectiveness is pending, the extent and breadth of physical activity programs offered by the primary care health system in Brazil appears to have much potential to help reduce physical inactivity, a global priority to help control the rising burden of NCDs 49 .

In conclusion, data from this study showed that four out of ten primary care units offered physical activity promotion programs. The characteristics of the physical activity programs in primary care in Brazil showed that activities included walking groups, physical assessments, stretching/relaxation exercises, and gym classes. Most activities occurred in the morning, with an average of one or two 30-minute weekly sessions. Physical education professionals were largely responsible for directing these activities. Primary care units usually offered additional informational activities, but most did not offer physical activities for school children. Most of the interventions occurred at the primary care unit and nearby community spaces. About half of the locations were evaluated as being good or adequate by the primary care unit coordinators. 


\section{Resumen}

El objetivo fue describir las características de los programas de actividad física en atención primaria, de acuerdo con el Centro de Apoyo a la Salud de la Familia (NASF) y las regiones de Brasil. Se realizó una encuesta transversal telefónica con 1.251 coordinadores de las unidades de salud. Se preguntó a los coordinadores acerca de la presencia y características de intervenciones de actividad física en funcionamiento. Cuatro de cada diez centros de salud reportaron tener una intervención de actividad física, especialmente, grupos de paseo. La mayor parte de las actividades se llevan a cabo por la mañana una vez o dos veces por semana con sesiones de 30 minutos o más. Los profesores de educación física son los principales responsables de la supervisión de las actividades. Los programas se llevan a cabo en la clínica o en otros espacios públicos. Estas características fueron similares en unidades con o sin NASF y mostraron una variación regional en su prevalencia. Estas características permitirán enfocar próximas acciones para promover la actividad física dentro de la atención primaria de salud.

Actividad Motora; Países en Desarrollo; Atención

Primaria de Salud; Salud de la Família

\section{Colaboradores}

G. A. O. Gomes contributed to the analysis and interpretation of the data, writing of the paper, critical revision of the intellectual content, and final approval of the manuscript to be submitted. E. Kokubun, E. Simões, M. Bracco and D. Cruz contributed to the critical revision of the intellectual content and final approval of the manuscript to be submitted. G. I. Mieke and A. A. Florindo contributed to the analysis and interpretation of the data, critical revision of the intellectual content, and final approval of the manuscript to be submitted. $\mathrm{L}$. R. Ramos conceived the project and contributed to the analysis and interpretation of the data. M. Pratt, D. C. Parra, D. Malta, F. Lobelo and P. C. Hallal conceived the project and contributed to the interpretation of the data, critical revision of the intellectual content, and final approval of the manuscript to be submitted.

\section{Acknowledgments}

The authors wish to thank all members of the GUIA team and the participating health care unit professionals. This study was funded through the Centers for Disease Control and Prevention's Prevention Research Centers Program contract U48/DP001903 (Applying EvidencePhysical Activity Recommendations in Brazil). The findings and conclusions in this report are those of the authors and do not necessarily represent the official position of the CDC.

\section{References}

1. Kohl HW, Craig CL, Lambert EV, Inoue S, Alkandari JRA, Leetongin G, et al. The pandemic of physical inactivity: global action for public health. Lancet 2012; 380:295-305.

2. Lee IM, Shiroma EJ, Lobelo F, Puska P, Blair SN, Katzmarzyk PT. Effect of physical inactivity on major non-communicable diseases worldwide: an analysis of burden of disease and life expectancy. Lancet 2012; 380:219-29.

3. Hallal PC, Andersen LB, Bull FC, Guthold R, Haskell W, Ekelund U. Global physical activity levels: surveillance progress, pitfalls, and prospects. Lancet 2012; 380:247-57.
4. Pratt M, Sarmiento OL, Montes F, Oglvie D, Bess H, Marcus $\mathrm{H}$, et al. The implications of megatrends in information and communication technology and transportation for changes in global physical activity. Lancet 2012; 380:282-93.

5. Cleland CL, Tully MA, Kee F, Cupples ME. The effectiveness of physical activity interventions in socio-economically disadvantaged communities: a systematic review. Prev Med 2012; 54:371-80.

6. Heath GW, Parra DC, Sarmiento OL. Evidencebased physical activity interventions: lessons from around the world. Lancet 2012; 380:272-81. 
7. Knuth AG, Malta DC, Cruz DK, Freitas PC, Lopes MP, Fagundes J, et al. Rede nacional de atividade física do Ministério da Saúde: resultados e estratégias avaliativas. Rev Bras Ativ Fís Saúde 2010; 15:229-34.

8. Malta DC, da Silva JB. Policies to promote physical activity in Brazil. Lancet 2012; 380:195-6.

9. Lachat C, Otchere S, Roberfroid D, Abubakari A, Seret FMA, Mileszevic J, et al. Diet and physical activity for the prevention of noncommunicable diseases in low-and middle-income countries: a systematic policy review. PLoS Med 2013; 10:e1001465.

10. Instituto Brasileiro de Geografia e Estatística. Pesquisa Nacional por Amostra de Domicílios. Um panorama da saúde no Brasil: acesso e utilização de serviços, condições de saúde e fatores de risco e proteção à saúde, 2008. Brasília: Instituto Brasileiro de Geografia e Estatística; 2008.

11. Departamento de Atenção Básica, Secretaria de Atenção à Saúde, Ministério da Saúde. Diretrizes do NASF: Núcleo de Apoio a Saúde da Família. Brasília: Minsitério da Saúde; 2006. (Caderno de Atenção Básica, 27).

12. Ministério da Saúde. Política Nacional de Atenção Básica. Brasília: Ministério da Saúde. 2006.

13. Orrow G, Kinmonth AL, Sanderson S, Sutton S. Effectiveness of physical activity promotion based in primary care: systematic review and meta-analysis of randomised controlled trials. BMJ 2012; 344: 1-17.

14. Siqueira FV, Facchini LA, Piccini RX, Tomasi E, Thumé E, Silveira DS, et al. Atividade física em adultos e idosos residentes em áreas de abrangência de unidades básicas de saúde de municípios das regiões Sul e Nordeste do Brasil. Cad Saúde Pública 2008; 24:39-54.

15. Rodrigues JD, Ferreira D, Silva P, Caminha I, Farias Junior JC. Inserção e atuação do profissional de educação física na atenção básica de saúde: revisão sistemática. Rev Bras Ativ Fís Saúde 2013; 18: 5-15.

16. Nakamura PM, Papini CB, Chiyoda A, Gomes GAO, Valdanha Netto A, Teixeira IP, et al. Programa de intervenção para a prática de atividade física: Saúde Ativa Rio Claro. Rev Bras Ativ Fís Saúde 2010; 15:128-32.

17. Kallings LV, Leijon M, Hellanius ML, Stahle A. Physical activity on prescription in primary health care: a followingup of physical activity level and quality of life. Scand J Med Sci Sports 2008; 18: 154-61.

18. Aittasalo M, Miilunpalo S, Kukkonen-Harjula K, Pasanen M. A randomized intervention of physical activity promotion and patient self-monitoring in primary health care. Prev Med 2006; 42:40-6.

19. Lawton BA, Rose SB, Elley CR, Dowell AC, Fenton A, Moyes SA. Exercise on prescription for women aged 40-74 recruited through primary care: two year randomised controlled trial. Br J Sports Med 2009; 43:120-3.
20. World Bank. Brazil addressing the challenge of non-communicable diseases in Brazil. https:// openknowledge.worldbank.org/handle/10986/ 8334 (accessed on 11/Jan/2014).

21. Hallal PC, Tenório MCM, Tassitano RM, Reis RS, Carvalho YM, Cruz DKA, et al. Avaliação do programa de promoção da atividade física Academia da Cidade de Recife, Pernambuco, Brasil: percepções de usuários e não-usuários. Cad Saúde Pública 2010; 26:70-8.

22. Hallal PC, Carvalho YM, Tassitano RM, Tenório MCM, Warschauer M, Reis RS, et al. Quali-quantitative evaluation of the 'Academia da Cidade' program from Recife, Brazil: perceptions of the professionals working in the program. Rev Bras Ativ Fís Saúde 2009; 14:104-14.

23. Simoes EJ, Hallal P, Pratt M, Ramos L, Munk M, Damascena W, et al. Effects of a community-based, professionally supervised intervention on physical activity levels among residents of Recife, Brazil. Am J Pub Health 2009; 99:68-75.

24. Gomes MA, Duarte MDFDS. Efetividade de uma intervenção de atividade física em adultos atendidos pela estratégia saúde da família: Programa Ação e Saúde Floripa-BRASIL. Rev Bras Ativ Fís Saúde 2008; 13:44-66.

25. Williams NH, Hendry M, France B, Lewis R, Wilkinson C. Effectiveness of exercise-referral schemes to promote physical activity in adults: systematic review. Br J Gen Pract 2007; 57:979-86.

26. US Department of Health and Human Services. Healthy People 2020. http://www.healthypeople. gov/2020/default.aspx (accessed on 12/Jan/2014).

27. Murphy SM, Edwards RT, Williams N, et al. An evaluation of the effectiveness and cost effectiveness of the National Exercise Referral Scheme in Wales, UK: a randomised controlled trial of a public health policy initiative. J Epidemiol Community Health 2012; 66:745-53.

28. Wanner M, Martin-Diener E, Bauer GF, Stamm H, Martin BW. Allez Hop, a nationwide programme for the promotion of physical activity in Switzerland: what is the evidence for a population impact after one decade of implementation? Br J Sports Med 2011; 45:1202-7.

29. Silva MP, Santos JWD, Souza AN, Tempesta SD, Avelino RA. Programa multidisciplinar para promoção da saúde envolvendo atividade física supervisionada: ações do PAFIPNES na atenção a saúde de mulheres em uma Unidade Básica de São José do Rio Pardo-SP. Rev Bras Ativ Fís Saúde 2011; 16:362-6.

30. Pratt M, Brownson RC, Ramos LR, Malta DC, Hallal PC, Reis RS, et al. Projeto GUIA: a model for understanding and promoting physical activity in Brazil and Latin America. J Phys Act Health 2010; 7 Suppl 2:S131-4.

31. Parra D, Hoehner C, Hallal P, Reis RS, Malta DC, Pratt M, et al. Scaling up of physical activity interventions in Brazil: how partnerships and research evidence contributed to policy action. Glob Health Promot 2014; 20:5-12. 
32. Departamento de Análise de Situação em Saúde, Secretaria de Vigilância em Saúde, Ministério da Saúde. Avaliação de efetividade de programas de atividade física no Brasil. Brasília: Ministério da Saúde; 2011.

33. Facchini LA, Piccini RX, Tomasi E, Thumé E. Desempenho do PSF no Sul e no Nordeste do Brasil: avaliação institucional e epidemiológica da Atenção Básica à Saúde. Ciênc Saúde Coletiva 2006; 11:669-81.

34. Facchini LA, Piccini RX, Tomasi E, Thumé E, Teixeira VA, Silva DS, et al. Avaliação de efetividade da Atenção Básica a Saúde em municípios das regiões Sul e Nordeste do Brasil: contribuições metodológicas. Cad Saúde Pública 2008; 24 Suppl 1:S159-72.

35. Garber CE, Blissmer B, Deschenes MR, Franklin BA, Lamonte MJ, Lee IM, et al. American College of Sports Medicine position stand. Quantity and quality of exercise for developing and maintaining cardiorespiratory, musculoskeletal, and neuromotor fitness in apparently healthy adults: guidance for prescribing exercise. Med Sci Sports Exerc 2011; 43:1334-59.

36. Fleming P, Godwin M. Lifestyle interventions in primary care. Can Fam Physician 2008; 54:1706-13.

37. Ronzani TM, Silva CM. O Programa Saúde da Família segundo profissionais de saúde, gestores e usuários. Ciênc Saúde Coletiva 2008; 13:23-34.

38. Ferreira AS. Competências gerenciais para unidades básicas do Sistema Único de Saúde. Ciênc Saúde Coletiva 2004; 9:69-76.

39. Ogata MN, Machado MLT, Catoia EA. Saúde da família como estratégia para mudança do modelo de atenção: representalções sociais dos usuários. Revista Eletrônica de Enfermagem [Online] 2009; 11:820-9.

40. American College of Sports Medicine. Exercise is Medicine. http://exerciseismedicine.org/ (accessed on 05/Mar/2013).
41. Sallis RE. Exercise is medicine and physicians need to prescribe it! Br J Sports Med 2009; 43:3-4.

42. Hoehner CM, Soares J, Parra DP, Ribeiro IC, Joshu $\mathrm{CE}$, Pratt $\mathrm{M}$, et al. Physical activity interventions in Latin America: a systematic review. Am J Prev Med 2008; 34:224-33.

43. Lobelo F, Garcia I, Holub CK, Nagle BJ, Arredondo EM, Barquera S, et al. School-based programs aimed at the prevention and treatment of obesity: evidence-based interventions for youth in Latin America. J School Health 2013; 83:668-77.

44. Holub C, Elder J, Arredondo E, Barquera S, Eisenberg CM, Romero LMS, et al. Obesity prevention among Latinos in the U.S. and Latin America: a systematic literature review. Am J Prev Med 2013; 44:529-37.

45. Holub CK, Lobelo F, Mehta SM, Sánchez Romero LM, Arredondo E, Elder JP. School-wide programs aimed at obesity among Latino youth in the United States: a review of the evidence. J School Health 2014; 84:239-46.

46. Bauman AE, Reis RS, Sallis JF, Wells JC, Loos RJF, Martin BW. Correlates of physical activity: why are some people physically active and others not? Lancet 2012; 380:258-71.

47. Hallal PC, Knuth AG. Physical activity and the need of qualitative research. Rev Bras Ciênc Esporte 2011; 33:181-92.

48. Ministério da Saúde. Municípios com financiamento destinado à projetos de atividade física. Brasília: Ministério da Saúde; 2013.

49. World Health Organization. Global action plan for the prevention and control of noncommunicable diseases, 2013-2020. Geneva: World Health Organization; 2013.

Submitted on 15/Apr/2013

Final version resubmitted on $06 / \mathrm{Jan} / 2014$

Approved on 18/Mar/2014 